\title{
Endocytotic activity in the endometrium during conceptus attachment in the cow
}

\author{
M. Guillomot*, K. J. Betteridge, D. Harvey and A. K. Goff \\ Centre de Recherche en Reproduction Animale, Faculté de Médecine Vétérinaire, Université de \\ Montréal, C.P. 5000, St-Hyacinthe, Québec, Canada J2S 7 C6
}

\begin{abstract}
Summary. The uptake of horseradish peroxidase tracer injected into the uterine lumen of the cow was studied during the period of conceptus attachment (Days 18-21; Day $0=$ oestrus) and also in cyclic animals. Endocytosis occurred in pregnant and non-pregnant cows but was especially marked when circulating progesterone concentrations were high. By $20 \mathrm{~min}$ after injection, the tracer was located in apical endocytotic vesicles and in organelles of the lysosomal system. In addition, some of the horseradish peroxidase-containing vesicles were associated with the lateral membranes of the cells and the tracer was also present in the intercellular spaces and beneath the basal membrane, especially in pregnant animals by the time of conceptus attachment. There was no evidence that pinopod-like functions could be attributed to large cytoplasmic protrusions from endometrial cells. Rather, the protrusions seemed to be involved in secretory processes. The presence of clear vesicles among the endocytotic vesicles suggested a coupled secretory-endocytotic activity of the cells, the significance of which remains to be determined.
\end{abstract}

\section{Introduction}

The cellular relationships that are established between the trophoblast and the luminal uterine epithelium play an important role during conceptus attachment (Enders, 1976) and have been the subject of several reports for the cow (Leiser, 1975; King, Atkinson \& Robertson, 1980; Wathes \& Wooding, 1980).

In a previous study, scanning electron microscopy was used to investigate changes of the luminal surface of the uterine cells during both the luteal phase of the oestrous cycle and early gestation (Guillomot \& Guay, 1982). The uterine eipthelial cells were shown to possess domeshaped cytoplasmic protrusions which were similar to the structures previously described for animals of several other species (rat: Psychoyos \& Mandon, 1971; mouse: Bergström \& Nillson, 1973; man: Ferenczy, Richart, Agate, Purkerson \& Dempsey, 1972; rabbit: Motta \& Andrews, 1976). However, there was no indication whether those structures were involved in secretory, endocytotic, or other functions. Ectoplasmic protrusions of the uterine cells of rats and mice have been shown to be involved in the reabsorption of uterine fluid, and have been termed 'pinopods' (Enders \& Nelson, 1973; Parr \& Parr, 1974, 1977). The endocytotic activity of the uterine epithelium seems important during implantation of the blastocyst in laboratory species (for a review see Parr, 1980a). We have therefore studied analogous processes in the cow. A brief account of parts of this work has been presented elsewhere (Guillomot \& Betteridge, 1983).

*Present address: Station de Physiologie Animale, INRA, 78350 Jouy-en-Josas, France. 


\section{Materials and Methods}

Animals, blood sampling, and progesterone assay. A total of 17 heifers was used and divided into three groups. Group 1 consisted of 9 animals studied at Days $14(\mathrm{~N}=1), 18(\mathrm{~N}=2), 20(\mathrm{~N}=2)$, and $22(\mathrm{~N}=2)$ after artificial insemination at oestrus (first day of oestrus = Day 0$)$ and at Day 2 $(\mathrm{N}=1)$ of the subsequent cycle. Group 2 comprised 5 non-inseminated animals studied at Days $14,18,19,20$ and 21 ( $\mathrm{N}=1$ for each day). In Group 3, 3 cyclic animals were fitted with progesterone-releasing devices (PRID, Abbott Laboratories, North Chicago, IL, U.S.A.) in the vagina from Day 14 until surgery at Day $21(\mathrm{~N}=2)$ or $22(\mathrm{~N}=1)$. Daily blood samples were taken from the coccygeal vein into evacuated tubes containing EDTA as an anticoagulant (Vacutainer, Becton-Dickinson, Mississaugua, Ontario) from Day 0 until the day of surgery. Plasma was separated by centrifugation and stored at $-20^{\circ} \mathrm{C}$ until assayed for its progesterone content by a radioimmunoassay (Harvey, Basu, Betteridge, Goff \& Kindahl, 1984). Progesterone was extracted from $100 \mu \mathrm{l}$ plasma by using redistilled petroleum ether. Recovery rates were between 75 and $85 \%$. Concentrations of progesterone were determined using a specific antiserum obtained from Immunotech, Montreal. Cross-reactivity for this antiserum was $100 \%$ for progesterone; $1 \%$ for pregnenolone; and $<0.1 \%$ for androstenedione, testosterone, 17-hydroxyprogesterone, oestrone, oestradiol, corticosterone and cortisol. The intra- and inter-assay coefficients of variation were both $<16 \%$. The sensitivity of the assay was $125 \mathrm{pg} / \mathrm{ml}$.

Surgical procedures. All intrauterine injections of horseradish peroxidase or control physiological saline $(0.9 \%(\mathrm{w} / \mathrm{v}) \mathrm{NaCl})$ were performed after exposing the uterus through a mid-ventral abdominal incision under general anaesthesia. Before surgery, animals were deprived of food for $3648 \mathrm{~h}$ and of water for $24 \mathrm{~h}$. Anaesthesia was induced by intravenous injection of thiamylal sodium $(10 \mathrm{mg} / \mathrm{kg}$ body weight) and maintained by halothane in oxygen in a closed-circuit system. The uterus was elevated to the incision and anchored there by a ligature of umbilical tape placed as far caudally as possible around the body of the uterus and then tied to a metal bar placed across the incision line (Betteridge \& Mitchell, 1974). The lumen of each uterine horn was occluded as near as possible to its base. Occlusion was achieved by a Foley catheter (No. 16 French-gauge which had been made solid by filling its lumen with silicone rubber). The catheter was inserted through a puncture made in the uterine wall with closed artery forceps, and its balloon cuff was inflated with $12 \mathrm{ml}$ saline.

Intraluminal injections were made on the ovarian side of these occlusions by means of a blunted 18-gauge needle introduced through the uterine wall. Horseradish peroxidase $(5 \mathrm{ml}$ of a $30 \mathrm{mg} / \mathrm{ml}$ solution: Type II, Sigma Chemical Co., St Louis, MO, U.S.A.) was injected into the horn ipsilateral to the corpus luteum, and, with two exceptions, $5 \mathrm{ml}$ of the control saline vehicle solution were injected into the contralateral horn. In one cyclic cow at Day 20, and in a pregnant cow at Day 22, the horseradish peroxidase solution was injected into both uterine horns. After 20 min the blood vessels to the uterus and ovaries were abruptly clamped and the genital tract was excised as rapidly as possible (within 1 min of clamping).

Fig. 1. Apical cytoplasm of an epithelial cell showing three types of endocytotic structures: large vesicles $(*)$, tubules (short arrows) and small round vesicles (arrowhead). Day 20 of pregnancy; lead citrate staining, $\times 30000$.

Fig. 2. The horseradish peroxidase is observed within membrane invaginations (arrowheads) at the base of the microvilli and, deeper, in the cytoplasm within vesicles (arrow). Day 20 of pregnancy; lead citrate staining, $\times 42000$.

Fig. 3. Control tissue from a uterine horn injected with saline. No endogenous peroxidase activity is observed. Day 19 of pregnancy; lead citrate staining, $\times 22000$. 

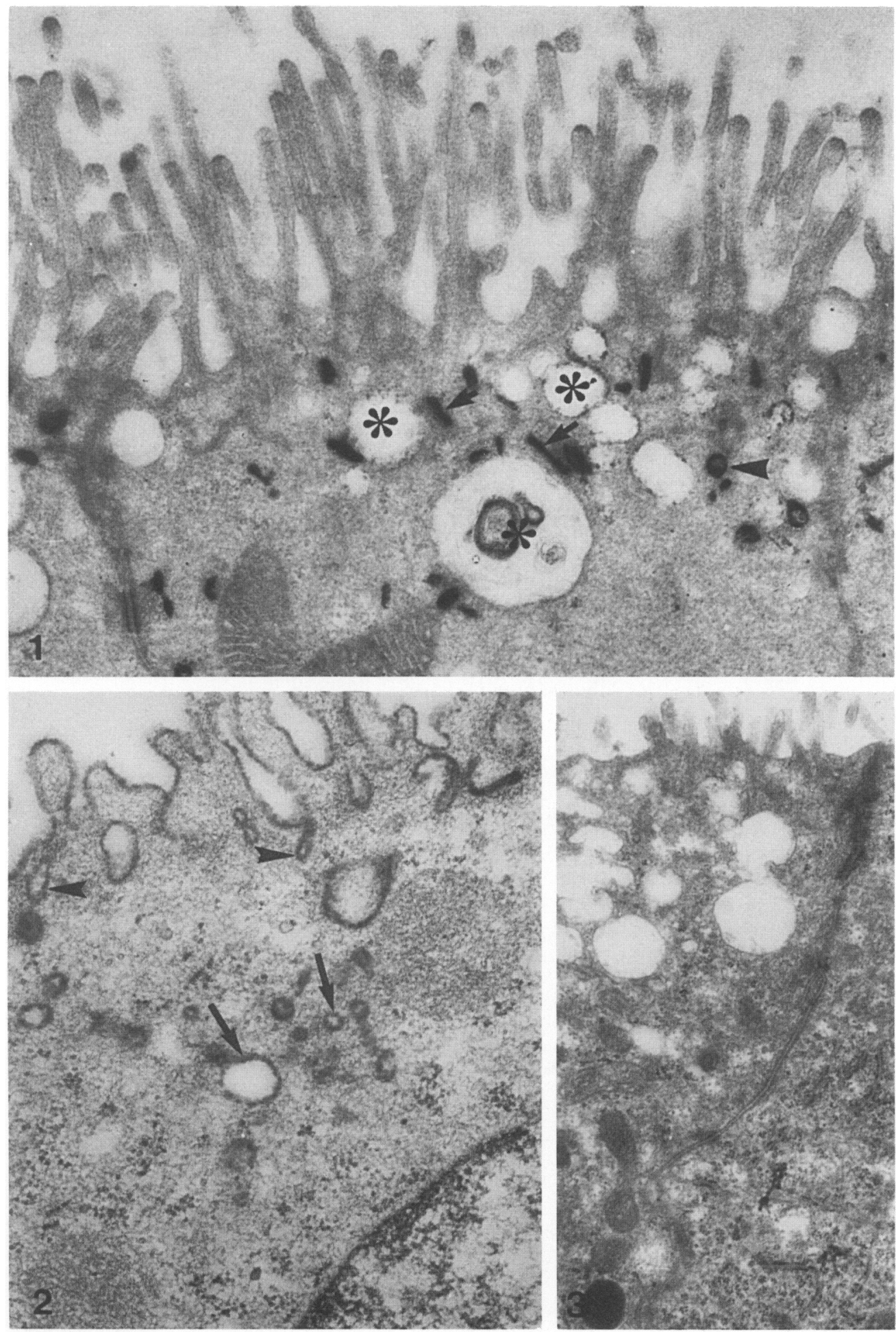
Tissue processing procedures. After separation of the uterine horns and removal of the Foley catheters, the lumen of each horn was flushed, first with a saline solution then with a fresh solution of fixative (1-2\% glutaraldehyde in $0.15 \mathrm{M}$-sodium cacodylate buffer, $\mathrm{pH} 7 \cdot 2$ ). Small pieces (about $5 \times 5 \times 1 \mathrm{~mm}$ ) of caruncular and intercaruncular endometrium were excised and immersed in the same fixative for $5 \mathrm{~h}$ at $4^{\circ} \mathrm{C}$, washed in the buffer, and stored overnight in fresh buffer at $4^{\circ} \mathrm{C}$. The horseradish peroxidase activity was demonstrated by the method of Graham \& Karnovsky (1966). Small pieces $\left(1 \mathrm{~mm}^{3}\right)$ from both uterine horns were incubated for $1 \mathrm{~h}$ at room temperature in darkness in a fresh solution of $0.5 \mathrm{mg}$ diaminobenzidine $/ \mathrm{ml}$ (Sigma) plus $\mathrm{H}_{2} \mathrm{O}_{2}$ in $0.05 \mathrm{M}-$ Tris- $\mathrm{HCl}$ buffer, $\mathrm{pH} 7 \cdot 6$. Control tissues were incubated in the same solution without $\mathrm{H}_{2} \mathrm{O}_{2}$. After three successive 10 -min washes in the sodium cacodylate buffer, the pieces were post-fixed in $1 \% \mathrm{OsO}_{4}$ solution for $1 \mathrm{~h}$ at room temperature, then dehydrated in ethanol and embedded in Epon. Five to 10 samples from each uterine horn were analysed. Ultrathin sections were examined with a Philips EM201 electron microscope, before or after light counterstaining with lead citrate.

\section{Results}

Embryos were recovered from 7 of the 9 inseminated animals of Group 1 and only these animals were considered pregnant. Progesterone concentrations in the peripheral plasma samples on the day of surgery ranged between 3.2 and $12.5 \mathrm{ng} / \mathrm{ml}$. The 2 other animals from this group ( 1 at Day 22,1 at Day 2 of the subsequent cycle) were regarded as non-pregnant and added to the 5 noninseminated heifers of Group 2. The progesterone concentrations in the samples taken on the day of surgery in these two inseminated, but not pregnant, heifers were both $0.2 \mathrm{ng} / \mathrm{ml}$, while concentrations in 4 of the 5 non-inseminated heifers were $16 \cdot 2,8 \cdot 5,1.5$ and $7.2 \mathrm{ng} / \mathrm{ml}$ for the Day-14, -18 , -20 and -21 animals respectively. The progesterone concentration was not determined in the sample from the 5 th non-inseminated animal (Day 19) because of an accident.

\section{Endocytosis in the microvillous cells}

In all the pregnant and non-pregnant animals, and at all the stages considered, the horseradish peroxidase was ingested by the uterine epithelial cells during the 20 -min incubation in vivo. No differences were observed between the horns ipsi- and contralateral to the corpus luteum, or between the caruncular and intercaruncular areas. The horseradish peroxidase activity was particularly evident within cytoplasmic vesicles located mainly within a $1 \mu \mathrm{m}$-deep area below the base of the microvillous border of the cells. The vesicles were of various shapes and sizes, even within the same cell (Fig. 1). In the largest vesicles $(0 \cdot 3-1 \mu \mathrm{m}$ in diameter), horseradish peroxidase coated the

Fig. 4. Apical cytoplasm of an endometrial cell showing numerous clear vesicles among peroxidase-containing vesicles (arrow). Day 19 of pregnancy; lead citrate staining, $\times 40000$.

Fig. 5. Cytoplasmic extrusion bulging in the uterine lumen (UL). The cytoplasm contains numerous clear vesicles $\left({ }^{*}\right)$ but few endocytotic vesicles (arrow). Note three large vesicles containing weakly electron-dense material in the lower right-hand corner. Day 20 of pregnancy; lead citrate staining, $\times 25000$.

Fig. 6. Multivesicular body containing peroxidase-reaction product. Day 20 of the oestrous cycle; unstained section, $\times 30000$.

Fig. 7. Micrograph taken from the mid-region of endometrial cells showing a group of lysosome-like bodies containing peroxidase activity. Day 14 of pregnancy; unstained section, $\times 5000$. 


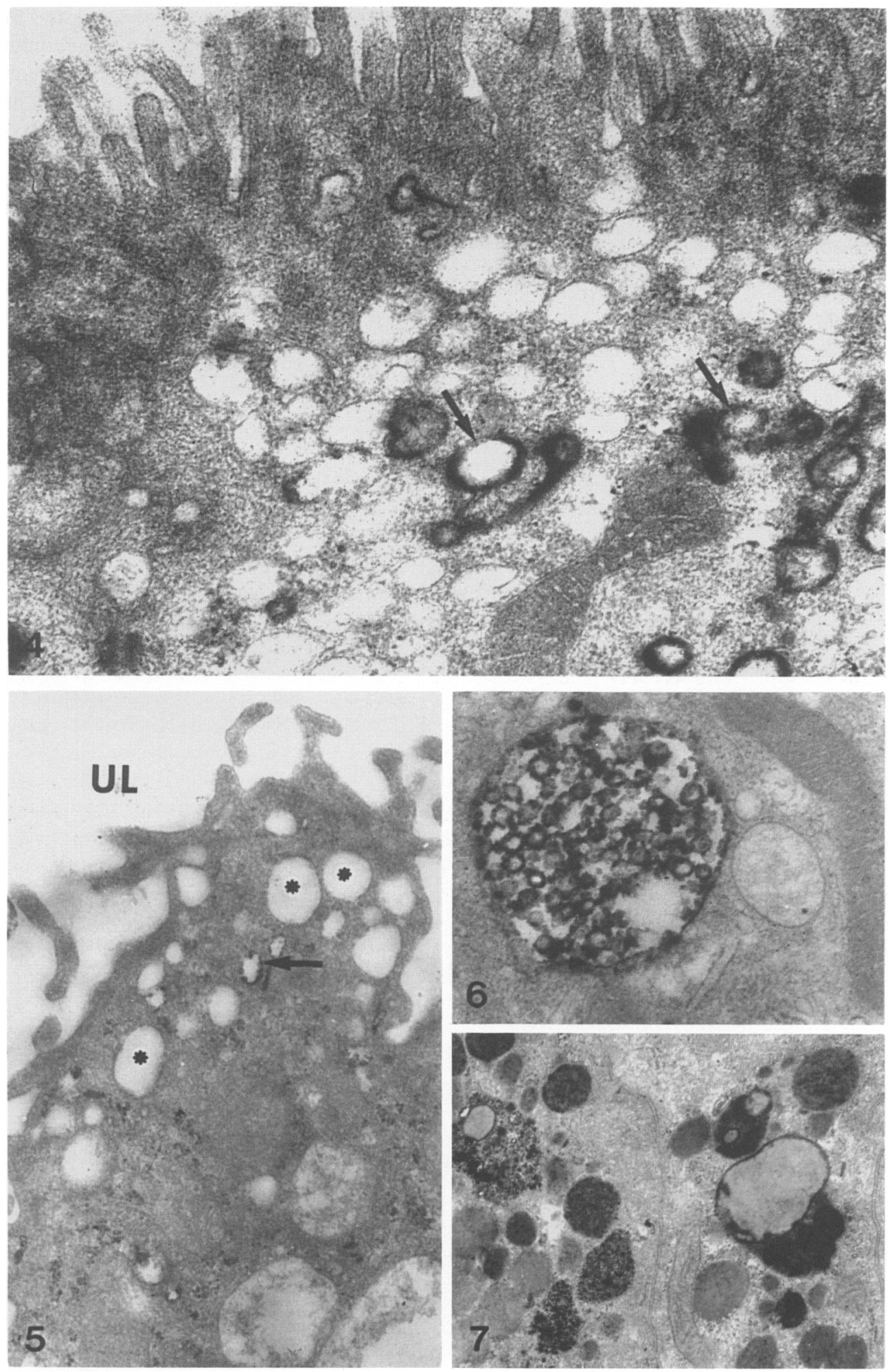


inner face of their limiting membrane (Fig. 1). Small vesicles (50-100 nm in diameter) and elongated or crescent-like tubules $(0 \cdot 1-0 \cdot 2 \mu \mathrm{m}$ long) were also filled with horseradish peroxidase, these structures being occasionally associated with the apical plasma membrane (Fig. 2).

In the control tissues from saline-injected uterine horns, no endogenous peroxidase activity was seen in the epithelial cells (Fig. 3). The samples incubated with diaminobenzidine in the absence of the $\mathrm{H}_{2} \mathrm{O}_{2}$ never showed a positive reaction for the peroxidase activity.

Clear vesicles $(0 \cdot 5-1 \mu \mathrm{m}$ in diameter) were frequently observed amongst the endocytotic vesicles. These vesicles never contained the tracer and were mainly located in the apical part of the cell (Fig. 4).

\section{Endocytosis in the cytoplasmic protrusions}

Besides microvillous cells, the epithelium also contained cells with dome-shaped protrusions bulging into the uterine lumen, as reported previously (Guillomot \& Guay, 1982). The apical surfaces of these protrusions were either smooth or covered with short microvilli. Their cytoplasm contained normal organelles and largely empty vesicles $(0 \cdot 3-1 \mu \mathrm{m}$ in diameter) which only rarely included tracer (Fig. 5).

\section{Fate of ingested tracer}

Below the apical cytoplasm the horseradish peroxidase tracer was present in multivesicular bodies (Fig. 6) and lysosome-like bodies (Fig. 7). By Day 18 of pregnancy, in 23/45 samples examined, the tracer was also present within the intercellular spaces below the tight junctions which were, themselves, always free of the tracer (Fig. 8). All the pregnant animals were represented in the 23 samples showing this feature. Small endocytotic vesicles $(50-100 \mathrm{~nm})$ were observed close to, or fused with, the lateral membranes of the cells (Fig. 9). The horseradish peroxidase reaction product was also found beneath the basement membrane in the stroma (Fig. 10). Although horseradish peroxidase also filled the entire cytoplasm of occasional dead cells within the epithelium, the presence of such dead cells was not associated with peroxidase being found either beneath the basal lamina or within the intercellular spaces between neighbouring cells (Fig. 11).

In sections of tissues from cyclic animals, the passage of horseradish peroxidase into the intercellular spaces was still observed in 10/30 blocks analysed from 4 cows at Days 14, 18, 19 and 21. However, this transepithelial transport was less frequently observed in tissues from the 2 inseminated but non-pregnant animals (at Day 22 in one; Day 2 of the subsequent cycle in the other) and from one cyclic cow at Day 20 (2/10,0/5 and 1/7 blocks observed, respectively).

Fig. 8. The horseradish peroxidase is present in the intercellular space below the apical tight junctions (brace) between endometrial cells. Day 18 of pregnancy; unstained section, $\times 2500$.

Fig. 9. Mid-region of endometrial cells. Some endocytotic vesicles (arrow) are fused with the lateral membranes and the intercellular space is filled with the peroxidase. Day 22 of pregnancy; unstained section, $\times 32000$.

Fig. 10. Basal poles of endometrial cells. Note the peroxidase-reaction product lining the intercellular spaces (arrows) and in the stroma (S: part of a stromal cell). Day 22 of pregnancy; unstained section, $\times 15000$.

Fig. 11. Basal poles of endometrial cells. The cytoplasm of a dead cell is filled with the tracer. Note that no reaction product is present below the basal lamina (arrow). Day 19 of the oestrous cycle; unstained section, $\times 4600$. 

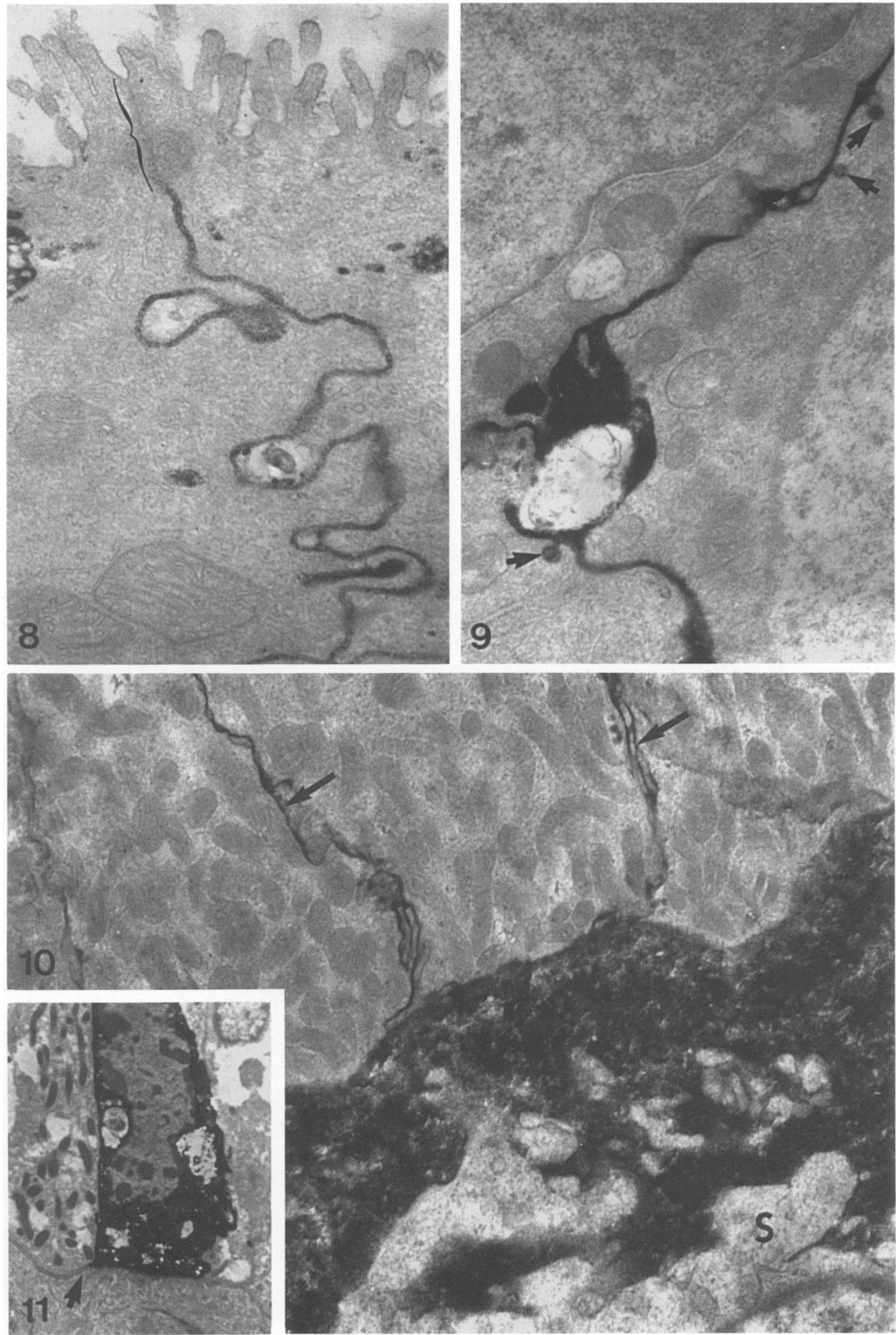


\section{Effect of progesterone treatment}

The ranges of progesterone concentrations in daily plasma samples after PRID insertion (Group 3) were $13.4-32.6 \mathrm{ng} / \mathrm{ml}$ and $6 \cdot 7-19.0 \mathrm{ng} / \mathrm{ml}$ respectively for the 2 animals hysterectomized on Day 21 , and $15.9-25.2 \mathrm{ng} / \mathrm{ml}$ for the animal hysterectomized on Day 22 . In these animals the horseradish peroxidase was observed in the same types of endocytotic vesicles and organelles as in untreated animals (Groups 1 and 2). The tracer was also present in the intercellular spaces and in the stroma.

\section{Discussion}

These results indicate that uterine epithelial cells of the cow have endocytotic properties during the early stages of gestation and during the oestrous cycle. Intraluminally-injected material can be absorbed by fluid-phase endocytosis. After endocytosis some of the ingested material is evidently transported to the lysosomal system while some is chanelled to the uterine stroma via the intercellular space after fusion of the endocytotic vesicles with the lateral membrane of the cell. Similar results were obtained in a previous study of the pregnant ewe, when using ferritin and horseradish peroxidase as tracers (Guillomot, 1979; Guillomot, Fléchon \& Wintenberger-Torres, 1981a).

The presence of intraluminal tracer in the uterine stroma has also been described for the rat (Sartor, 1969; Vokaer \& Leroy, 1962; Abe, Takahashi \& Masaki, 1981). However, contradictory observations have been reported by Leroy, VanHoeck \& Bogaert (1976) and by Parr \& Parr (1978) who found no evidence of exocytosis of the tracer at the base of the epithelial cells. Leroy et al. (1976) pointed out that this discrepancy could, in their case, have been due to different experimental conditions, whereas Parr \& Parr (1978) suggested that the previous observations may have been due to an uptake of luminal material by macrophages. In the present study it is clear that the transport of the tracer was via a transepithelial pathway and was not mediated by macrophages. Moreover, the transepithelial route evidently does not involve mere passive diffusion through dead cells because the presence of horseradish peroxidase within these is not associated with its presence beneath their adjacent basal lamina or within neighbouring intercellular spaces. In the rat, Enders \& Nelson (1973) also reported passage of horseradish peroxidase and ferritin into the intercellular spaces after injection into the uterine lumen, but only occasionally, and after prolonged exposure to the tracer. A reverse transepithelial transport of horseradish peroxidase from the uterine stroma to the lumen has been described after intravenous injection of the tracer (Parr, 1980b).

Although no statistical analysis was used in the present study, the transepithelial transport of horseradish peroxidase was observed more frequently in animals with high plasma concentrations of progesterone ( $\geqslant 3 \mathrm{ng} / \mathrm{ml}$ ) (whether pregnant, cyclic or PRID-treated) than in the only 3 animals in which plasma progesterone concentrations were $\leqslant 1.5 \mathrm{ng} / \mathrm{ml}$ (whether cyclic or inseminated but not pregnant). The suggestion that progesterone could control the endocytotic activity of the uterine epithelium and/or the movements of the endocytotic vesicles within the cells is supported by previous studies in the rat, as endocytosis is observed at Day 5 of pregnancy and during pseudopregnancy but not in cyclic animals (Vokaer, 1952; Vokaer \& Leroy, 1962). In ovariectomized rats, uterine epithelial endocytosis is at least enhanced by (Leroy et al., 1976), and probably depends upon (Parr, 1983), treatment with progesterone.

It has been suggested by Parr \& Parr (1982) that the cytoplasmic protrusions previously described on the cell surface of the rabbit endometrium were mostly artefactual and due to immersion fixation. This seems unlikely because the protrusions have also been observed by others after perfusion fixation (Segalen, Lescoat \& Chambon, 1982; Lescoat, 1983). In our previous studies of the ewe we also used a perfusion fixation of the uterine horns and we still observed these apical protrusions on the epithelial cells (Guillomot et al., 1981b). The cytoplasmic protrusions seen in this, and a previous study (Guillomot \& Guay, 1982), did not present the typical large vacuoles 
described in the pinopods of rodents (Enders \& Nelson, 1973; Parr \& Parr, 1974, 1977). In the present study, only a few cytoplasmic vesicles containing the tracer were observed in the protrusions and most of the apical vesicles were free of horseradish peroxidase. This suggests that the protrusions could be mainly involved in secretory activity rather than in pinocytosis. Similarly, in the rabbit, no evidence of endocytotic activity could be demonstrated in analogous structures of the endometrial cells (Segalen, 1979; Parr \& Parr, 1982).

The presence of clear and empty vesicles close to the endocytotic vesicles in cytoplasmic protrusions and microvillous cells suggests that endocytosis can be coupled with exocytosis or secretion in the same cell. Coupled processes of this type have been demonstrated in numerous other tissues (Kalina \& Robinovitch, 1975; Silverstein, Steinman \& Cohn, 1977; Farquhar, 1978). It has also been suggested that these clear vesicles originate from the Golgi complex and could be associated with the recycling of the plasma membrane concomitantly with endocytosis (Parr, 1980a).

One can only speculate on the importance of endocytosis in the process of implantation, although various roles for the process have been suggested (see Enders \& Nelson, 1973; Parr, $1980 \mathrm{a}, \mathrm{b}$ ). The results presented here show that, in the cow, horseradish peroxidase (and, by implication, other non-hydrolysed macromolecules) can enter the cell by endocytosis and reach the uterine stroma near the time of conceptus attachment. The possible significance of this to our understanding of trophoblast-endometrial relationships, the conveyance of embryonic signals, and maternal recognition of pregnancy in cattle remains to be determined.

We thank M. Robert Bériault and Mlle Carmen Léveillée for surgical and technical assistance; the farm staff of the CRRA for care of the animals; and Agriculture Canada and the Natural Sciences and Engineering Research Council of Canada for financial support.

\section{References}

Abe, T., Takahashi, J. \& Masaki, J. (1981) Uptake of trypan blue in the uterine epithelium of the rat during early pseudopregnancy. Tohoku J. Agric. Res. 31, 207-214.

Bergström, S. \& Nilsson, O. (1973) Various types of embryo-endometrial contacts during delay of implantation in the mouse. J. Reprod. Fert. 32, $531-533$.

Betteridge, K.J. \& Mitchell, D. (1974) Embryo transfer in cattle: experience of twenty-four completed cases. Theriogenology 1, 69-82.

Enders, A.C. (1976) Anatomical aspects of implantation. J. Reprod. Fert., Suppl. 25, 1-15.

Enders, A.C. \& Nelson, D.M. (1973) Pinocytotic activity of the uterus of the rat. Am. J. Anat. 138, 277-300.

Farquhar, M.G. (1978) Recovery of surface membrane in anterior pituitary cells. J. Cell Biol. 79, R35-R42.

Ferenczy, A., Richart, R.M., Agate, F.J., Purkerson, M.L. \& Dempsey, E.W. (1972) Scanning electron microscopy of the human endometrial surface epithelium. Fert. Steril. 23, 515-521.

Graham, R.C. \& Karnovsky, M.J. (1966) The early stages of absorption of injected horseradish peroxidase in the proximal tubules of mouse kidney: ultrastructural cytochemistry by a new technique. J. Histochem. Cytochem. 14, 291-302.

Guillomot, M. (1979) Etude des modifications ultrastructurales et cytochimiques de la surface épitheliale utérine et du blastocyste de brebis au cours de l'implantation. Thèse $3 \mathrm{e}$ cycle, Universite $\mathrm{P}$. et $\mathrm{M}$. Curie, Paris.
Guillomot, M. \& Betteridge, K.J. (1983) Endocytose de macromolécules par l'épithelium utérin au cours de l'implantation chez la vache. Biol. Cell. 48, 13a, Abstr.

Guillomot, M. \& Guay, P. (1982) Ultrastructural features of the cell surfaces of uterine and trophoblastic epithelia during embryo attachment in the cow. Anat. Rec. 204, 31 5-322.

Guillornot, M., Fléchon, J.E. \& Winterberger-Torres, S. (1981a) Cellular contact between the trophoblast and the endometrium at implantation in the ewe. In Cellular and Molecular Aspects of Implantation, pp. 446 449. Eds S. R. Glasser \& D. W. Bullock. Plenum, New York.

Guillomot, M., Fléchon, J.E. \& Winterberger-Torres, S. (1981b) Conceptus attachment in the ewe: an ultrastructural study. Placenta 2, 169-182.

Harvey, D., Basu, S., Betteridge, K.J., Goff, A.K. \& Kindahl, H. (1984) The influence of pregnancy on $\mathrm{PGF}_{2}$ secretion in cattie. II. Urinary levels of 11 ketotetranor PGF metabolites and plasma progesterone concentrations during the oestrous cycle and early pregnancy. Anim. Reprod. Sci. 7, 217-236.

Kalina, M. \& Robinovitch, R. (1975) Exocytosis couples to endocytosis of ferritin in parotid acinar cells from isoprenalin stimulated rats. Cell Tiss. Res. 163, 373-382.

King, G.J., Atkinson, B.A. \& Robertson, H.A. (1980) Development of the bovine placentome from Days 20 to 29 of gestation. J. Reprod. Fert. 59, 95-100.

Leiser, R. (1975) Kontaktaufnahme zwischen tropho- 
blast und uterusepithel Wahrend der Fruhem Implantation beim Rind. Anat. Histol. Embryol. 4, 63-86.

Leroy, F., Van Hoeck, J. \& Bogaert, C. (1976) Hormonal control of pinocytosis in the uterine epithelium of the rat. J. Reprod. Fert. 47, 59-62.

Lescoat, D. (1983) Influence of intra-uterine infusions of blastocyst tissue homogenate on the ultrastructure of spayed rabbit uterus. $J$. submicrosc. Cytol. 15, 645-653.

Motta, P. \& Andrews, P.M. (1976) Scanning electron microscopy of the endometrium during the secretory phase. J. Anat. 122, 315-322.

Parr, M.B. (1980a) Endocytosis in the uterine epithelium during early pregnancy. Prog. Reprod. Biol. 7, 81-91.

Parr, M.B. (1980b) Endocytosis at the basal and lateral membrane of rat uterine epithelial cells during early pregnancy. J. Reprod. Fert. 60, 95-99.

Parr, M.B. (1983) Relationship of uterine closure to ovarian hormones and endocytosis in the rat. $J$, Reprod. Fert. 68, 185-188.

Parr, M.B. \& Parr, E.L. (1974) Uterine luminal epithelium: protrusions mediate endocytosis not apocrine secretion in the rat. Biol. Reprod. 11, 220-233.

Parr, M.B. \& Parr, E.L., (1977) Endocytosis in the uterine epithelium of the mouse. J. Reprod. Fert. 50,151-153.

Parr, M.B. \& Parr, E.L. (1978) Uptake and fate of ferritin in the uterine epithelium of the rat during early pregnancy. J. Reprod. Fert. 52, 183-188.

Parr, M.B. \& Parr, E.L. (1982) Relationship of apical domes in the rabbit uterine epithelium during the peri-implantation period to endocytosis, apocrine secretion and fixation. J. Reprod. Fert. 66, 739-744.
Psychoyos, A. \& Mandon, P. (1971) Etude de la surface de l'épithélium utérin au microscope électronique à balayage. Observations chez la ratte au 4è et au 5 è jour de la gestation. C. r. hebd. Séance. Acad. Sci. Paris D 272, 2723 2729.

Sartor, P. (1969) Athrocytose du bleu trypan par l'endomètre de la ratte. Manifestation du processus en fonction du contexte hormonal. C. r. Séanc. Soc. Biol. 163, 2564-2567.

Segalen, J. (1979) Rapports de l'oeuf et de l'utérus avant et pendant l'ovoimplantation chez le lapin. Etudes aux microscopes électroniques à balayage et en transmission. Thèse de 3e cycle. Université Rennes.

Segalen, J., Lescoat, D. \& Chambon, Y. (1982) Ultrastructural aspects of uterine secretion during the establishment of pregnancy in the rabbit: role of the egg. J. Anat. 135, 281-289.

Silverstein, S.C., Steinman, R.M. \& Cohn, Z.A. (1977) Endocytosis. Ann. Rev. Biochem. 46, 669-722.

Vokaer, R. (1952) Recherches histophysiologiques sur l'endomètre du rat, en particulier sur le conditionnement hormonal et ses propriétés athrocytaires. Archs Biol. Liège 63, I-84.

Vokaer, R. \& Leroy, F. (1962) Experimental study on local factors in the process of ovo-implantation in the rat. Am. J. Obstet. Gynec. 83, 141-148.

Wathes, D.C. \& Wooding, F.B.P. (1980) An electron microscopic study of implantation in the cow. Am.J. Anat. 159, 285-306.

Received 7 November 1985 